\title{
Pelaksanaan Ekstrakurikuler SepakBola Sekolah Dasar Negeri 06 Balah Hilir Lubuk Alung
}

\author{
Doni Mirwanto ${ }^{1}$, Syahrastani ${ }^{2}$ \\ ${ }^{12}$ Fakultas Ilmu Keolahragaan, Universitas Negeri Padang, Indonesia. \\ E-mail: mirwanto@gmail.com ${ }^{1}$, syahrastani@yahoo.com²
}

\begin{abstract}
Abstrak
Berdasarkan pengamatan yang penulis lakukan di Sekolah Dasar Negeri 06 Balah Hilir Lubuk Alung Kabupaten Padang Pariaman, kegiatan ekstrakurikuler sepakbola kurang terlaksana dengan baik atau belum berjalan dengan benar karena ditemukan kehadiran siswa yang sedikit pada setiap kali pertemuan. Tujuan penelitian adalah untuk memperoleh gambaran yang jelas tentang : Pelatih, Sarana dan prasarana serta Dukungan orang tua pada pelaksanaan ekstrakurikuler sepakbola Sekolah Dasar Negeri 06 Balah Hilir Lubuk Alung Kabupaten Padang Pariaman.

Jenis penelitian ini adalah jenis penelitian "Deskriptif". Penelitian ini ditujukan kepada pengungkapan masalah yang terjadi tentang pelaksanaan ekstrakurikuler sepakbola Sekolah Dasar Negeri 06 Balah Hilir Lubuk Alung Kabupaten Padang Pariaman. Penelitian ini dilaksanakan pada Bulan Maret - April tahun 2013. Populasi dan sampel dalam penelitian ini adalah siswa laki-laki yang aktif dalam pelaksanaan ekstrakurikuler sepakbola berjumlah 43 orang. Jenis dan sumber data adalah data primer dan data sekunder. Analisis data dilakukan dengan menggunakan analisis deskriptif.

Berdasarkan hasil penelitian ditemukan skor rata-rata indikator pelatih 2,66 dengan Tingkat Capaian Responden (TCR) sebesar 53,16\% masuk dalam kategori kurang. Berdasarkan hasil penelitian ditemukan skor rata-rata indikator ketersediaan sarana dan prasaran 2,67 dengan Tingkat Capaian Responden (TCR) sebesar 53,42\% masuk dalam kategori kurang. Berdasarkan hasil penelitian ditemukan skor rata-rata indikator dukungan orang tua 2,90 dengan Tingkat Capaian Responden (TCR) sebesar 57,98\% masuk dalam kategori kurang.
\end{abstract}

Kata Kunci: Ekstrakurikuler, Sepak Bola, Sekolah Sepak Bola.

\section{Abstract}

Abstract english version, written using Time New Roman-11, italic. Abstract containsresearch aim/purpose, method, and reseach results; written in 1 paragraph, single space among rows, using past tense sentences.

Keywords: one or more word(s) or phrase(s), that it's important, spesific, or representative for the article

\section{PENDAHULUAN}

Sepakbola adalah salah satu cabang olahraga yang sudah memasyarakat di Indonesia. Hal ini dapat dilihat begitu banyak orang yang menggemarinya, baik sebagai penonton maupun langsung sebagai pemain. Mulai dari perkotaan sampai pedesaan, dari kalangan anak-anak sampai orang tua, bahkan dari kaum wanita pun tidak mau ketinggalan. Alasan merekapun bermacam-macam, ada yang sekedar mengisi waktu luang, mencari hiburan, sampai yang ingin mencapai prestasi yang tinggi. Tempat dan waktu mereka bermainpun beragam pula sesuai dengan situasi dan kondisi yang mereka miliki, ada yang di pantai, halaman rumah, dalam ruangan, sampai lapangan yang sebenarnya.

Namun pada prinsipnya sepertinya pencapaian prestasi tersebut seperti yang dinyatakan (Asnaldi, 2016) "Seiring berjalannya waktu perkembangan ilmu pengetahuan serta teknologi dewasa ini yang berlangsung dengan cepat, banyak menyebabkan pergeseran nilai- nilai kehidupan, baik itu nilai sosial, budaya,ekonomi, politik bahkan tanpa terkecuali nilai-nilai olahraga itu 
Sport Science: Jurnal Sain Olahraga dan Pendidikan Jasmani ISSN 114-562X (Cetak), ISSN XXXX-XXXX(Online)

http://sportscience.ppj.unp.ac.id/index.php/jss/index

sendiri”.Berdasarkan penjelasan tersbut di arahkan kepada persepsi tentang permainan sepakbola merupakan suatu usaha untuk menguasai bola dan merebutnya kembali bila sedang dikuasai oleh lawan.

Oleh karena itu, untuk dapat bermain sepakbola harus menguasai teknik-teknik dasar sepakbola yang baik. Untuk dapat menghasilkan permainan sepakbola yang optimal, maka seorang pemain harus dapat menguasai teknik-teknik dalam permainan. Teknik dasar bermain sepakbola adalah merupakan kemampuan untuk melakukan gerakan-gerakan atau mengerjakan sesuatu yang terlepas sama sekali dari permainan sepakbola.

Aspek lain yang memberikan kontribusi positif adalah sarana dan prasarana yang menunjang dalam permainan sepakbola, karena sarana dan prasarana seperti bola, lapangan dan lainnya merupakan pondasi dalam permainan sepakbola. Sarana prasarana yang tidak memadai akan mempersulit berjalan permainan sepakbola. Urain ini diperkuat berdasarkan pendapat (Asnaldi, 2015) "Agar tercapainya ideal di atas, maka dalam melaksanakan pengajaran pendidikan jasmani dan kesehatan sebaiknya guru penjaskes harus mempertimbangkan kemampuannya. metoda. materi. akitivitas belajar. sarana dan prasarana serta motivasi siswa". Seangkan aspek ekternal yang menunjang kegiatan sepakbola adalah dukungan orang tua, karena dukungan yang diberikan oleh orang terdekat merupakan motivasi eksternal yang menunjang seseorang lebih bersemangat dalam permainan sepakbola.

Di sekolah penyajian pembelajaran pendidikan jasmani hanya dengan waktu $2 \times 35$ menit dalam seminggu. Ini belum sepenuhnya mampu meningkatkan kesegaran jasmani para siswa, maka dari itu perlu menambahkan pembelajaran dengan melakukan kegiatan ekstrakurikuler. Dengan adanya kegiatan ekstrakurikuler ini diharapkan mampu meningkatkan kesegaran jasmani, menyalurkan dan mengembangkan bakat dan minat peserta didik. Sesuai dengan pendapat (Asnaldi et al., 2018) "Hasil belajar penjasorkes tidak hanya dipengaruhi oleh variabel motivasi olahraga dan kemampuan motorik saja, melainkan banyak variabel lain yang dapat mempengaruhi hasil belajar penjasorkes siswa". Untuk tercapainya kesegaran jasmani diharapkan proses pembelajaran perlu dilakukan secara efektif dan fungsional sekaligus terpadu.

Ekstrakurikuler merupakan wahana pembinaan siswa yang dilakukan di luar jam pembelajaran biasa dan pada waktu libur sekolah baik secara berkala atau pada waktu-waktu tertentu. Karena sifat dari ekstrakurikuler tersebut bertujuan untuk menunjang kegiatan intrakurikuler dan kokurikuler. Dari penjelasan ini maka kegiatan ekstrakurikuler adalah kegiatan yang dilakukan di luar jam pelajaran untuk mengembangkan, meningkatkan prestasi olahraga, menyalurkan minat dan bakat pada siswa, agar dapat tumbuh secara wajar, teratur, terarah dan optimal.

Dalam rangka memantapkan sekolah serta menunjang terwujudnya pendidikan yang diharapkan. Melalui kegiatan ekstrakurikuler ini semua potensi tersebut dipupuk, ditumbuhkan, dan diperlukan dukungan orang tua. Tanpa dukungan tersebut, maka seseorang siswa sulit menjadi seorang yang berprestasi. Berdasarkan pengamatan yang penulis lakukan di Sekolah Dasar Negeri 06 Balah Hilir Lubuk Alung Kabupaten Padang Pariaman, kegiatan ekstrakurikuler sepakbola kurang terlaksana dengan baik atau belum berjalan dengan benar karena ditemukan kehadiran siswa yang sedikit pada setiap kali pertemuan. Senada dengan yang dinyatakan oleh (Asnaldi et al., 2018) ".Semua ini merupakan tanggung jawab bersama, baik siswa, guru dan orang tua, karena orang tua penting memberikan perhatian dan pengawasan terhadap anaknya dalam belajar, sehingga hasil belajar dapat ditingkatkan". Sedikitnya kehadiran siswa pada setiap kegiatan tersebut mungkin dipengaruhi oleh kurangnya dukungan orang tua, cuaca yang buruk, dukungan dari sekolah, dukungan masyarakat lingkungan, serta padatnya waktu tambahan pelajaran siswa dan minat siswa itu sendiri.

Hal lain yang ditemukan ialah guru dalam menyampaikan materi tidak sesuai dengan prakteknya, tidak tersedianya sarana dan prasarana yang baik dan lengkap dalam pelaksanaan kegiatan ekstrakurikuler sepakbola, guru jarang melakukan evaluasi dan tidak adanya dilakukan praktek secara 
rutin dan berkelanjutan. Usaha ektrakurikuler sepakbola untuk mencapai suatu prestasi dalam sepakbola merupakan usaha yang benar-benar harus diperhitungkan secara matang dengan unsurunsur pembinaan, dalam artian harus ada yang dibina (Atlet) ada yang membina (Pelatih), adanya mekanisme kerjasama organisasi (Pengurus) dan tak lepas dari kelengkapan serta kualitas sarana dan prasarana yang dimiliki oleh sebuah persatuan.

Membina sebuah persatuan sepakbola sangatlah diperlukan kerjasama yang baik antar kekompakkan, karena tanpa kerjasama yang baik antara Atlet, Pelatih dan Pengurus, Organisasi akan sangat sulit meraih prestasi yang tinggi. Menurut (Rosmawati, 2016) "Yang tidak kalah pentingnya sekarang ini terus dikembangkan dan ditingkatkan adalah teknik, taktik dan strategi yang diterapkan para pemain maupun pelatih dalam menghadapi suatu pertandingan". Semua hal tersebut saling terkait satu sama lainnya, serta diperlukan evaluasi untuk menentukan majunya kegiatan ekstrakurikuler sepakbola yang dibina. Antara komponen-komponen ini dapat digambarkan sebuah kerangka tentang.

Pelaksanaan Ekstrakurikuler Sepakbola Sekolah Dasar Negeri 06 Balah Hilir Lubuk Alung Kabupaten Padang Pariaman Kerangka Tersebut dapat digambarkan seperti apakah pelatih / pembina ada hubungan dengan pelaksanaan ekstrakurikuler sepakbola Sekolah Dasar Negeri 06 Balah Hilir Lubuk Alung Kabupaten Padang Pariaman. Apakah sarana prasarana ada hubungan dengan pelaksanaan ekstrakurikuler sepakbola Sekolah Dasar Negeri 06 Balah Hilir Lubuk Alung Kabupaten Padang Pariaman. Apakah dukungan orang tua ada hubungan dengan pelaksanaan ekstrakurikuler sepakbola Sekolah Dasar Negeri 06 Balah Hilir Lubuk Alung Kabupaten Padang Pariaman. Dari pernyataan-pernyataan tersebut peneliti dapat beranggapan bahwa kegiatan ekstrakurikuler sepakbola di Sekolah Dasar Negeri 06 Balah Hilir Lubuk Alung Kabupaten Padang Pariaman kurang terlaksananya dengan baik.

\section{METODE}

Jenis penelitian ini adalah jenis penelitian "Deskriptif" karena penelitian ini ditujukan kepada pengungkapan masalah yang terjadi tentang Pelaksanaan Ekstrakurikuler Sepakbola Sekolah Dasar Negeri 06 Balah Hilir Lubuk Alung Kabupaten Padang Pariaman sebagai mana adanya, dan juga mengumpulkan informasi atau keterangan mengenahi suatu objek dengan menggambarkan apa adanya. Penelitian ini bertempat di Sekolah Dasar Negeri 06 Balah Hilir Lubuk Alung Kabupaten Padang Pariaman yang diteliti adalah siswa laki-laki yang aktif mengikuti kegiatan ekstrakurikuler sepakbola.

Populasi dalam penelitian ini adalah seluruh siswa laki-laki yang aktif dalam pelaksanaan ekstrakurikuler sepakbola di Sekolah Dasar Negeri 06 Balah Hilir Lubuk Alung Kabupaten Padang Pariaman yang berjumlah 43 orang. Berdasarkan populasi di atas, maka yang dijadikan sampel dalam penelitian ini adalah siswa laki-laki yang aktif dalam kegiatan ekstrakurikuler sepakbola. Sedangkan penarikan sampel dilakukan dengan Total Sampling. Dipertegas menurut pendapat (Redawati et al., 2017) "untuk lebih representatif dalam menghimpun informasi data, maka untuk sampel diambil total sampling".Data primer dikumpulkan dengan menggunakan daftar pertanyaan atau angket yang telah disiapkan sebelumnya.

Sedangkan data sekunder didapatkan melalui observasi dan pencatatan langsung dari sumber data. Teknik pengumpulan data yang digunakan dalam penelitian ini adalah menggunakan daftar pertanyaan atau angket. Teknik pengumpulan data dilakukan dengan menyebarkan angket kepada murid kelas IV dan V, alat pengukuran menggunakan skala Liker dengan 4 alternatif jawaban. Penyusunan angket dilakukan dengan langkah, membuat kisi-kisi angket dengan cara menentukan variabel yang akan diteliti serta menjabarkan variabel tersebut menjadi indikator-indikator.Teknik analisis data yang digunakan adalah analisis deskriptif dengan menggunakan rumus dari (Suharsimi Arikunto, 1990:35)

\section{HASIL DAN PEMBAHASAN}




\section{Hasil Penelitian}

Sekolah Dasar Negeri 06 Balah Hilir Lubuk Alung Kabupaten Padang Pariaman berada di Jalan lintas Padang Agam didirikan tahun $1975 \mathrm{di}$ atas tanah dengan luas $1.436 \mathrm{~m}^{2}$. Berdasarkan hasil penelitian mengenai pelaksanaan ekstrakurikuler sepakbola dapat disajikan pada berikut ini :

\section{Indikator Dukungan Pelatih}

Dari Analisis yang dilakukan diperoleh informasi bahwa skor rata-rata indikator dukungan pelatih 2,66 dengan Tingkat Capaian Responden (TCR) sebesar 53,16\%. Hal ini menunjukkan bahwa variabel dukungan pelatih dalam pelaksanaan ekstrakurikuler sepakbola masuk dalam kategori kurang. Dengan demikian dapat disimpulkan bahwa pada umumnya pelatih kurang dalam memberikan dukungan kepada siswa dalam pembelajaran ekstrakurikuler sepakbola.

\section{Indikator Sarana dan Prasarana}

Pada analisa data diperoleh informasi bahwa skor rata-rata indikator ketersediaan sarana dan prasaran 2,67 dengan Tingkat Capaian Responden (TCR) sebesar 53,42\%. Hal ini menunjukkan bahwa variabel ketersediaan saran dan prasarana dalam pelaksanaan ekstrakurikuler sepakbola masuk dalam kategori kurang. Dengan demikian dapat disimpulkan bahwa pada umumnya ketersediaan saran dan prasarana dalam pembelajarn ekstrakurikuler sepakbola masih kurang.

\section{Indikator Dukungan Orang Tua}

Analisis Deskripsi diperoleh informasi bahwa skor rata-rata indikator dukungan orang tua 2,90 dengan Tingkat Capaian Responden (TCR) sebesar 57,98\%. Hal ini menunjukkan bahwa variabel dukungan orang tua dalam pelaksanaan ekstrakurikuler sepakbola masuk dalam kategori kurang. Dengan demikian dapat disimpulkan bahwa pada umumnya orang tua kurang mendukung dalam pembelajarn ekstrakurikuler sepakbola masih kurang.

\section{Pembahasan}

Berdasarkan hasil penelitian ditemukan skor rata-rata indikator dukungan pelatih 2,66 dengan Tingkat Capaian Responden (TCR) sebesar 53,16\%. Hal ini menunjukkan bahwa variabel dukungan pelatih dalam pelaksanaan ekstrakurikuler sepakbola masuk dalam kategori kurang. Dengan demikian dapat disimpulkan bahwa pada umumnya pelatih kurang dalam memberikan dukungan kepada siswa dalam pembelajaran ekstrakurikuler sepakbola.

Dukungan pelatih dapat berupa menyediakan sarana prasarana guna pelaksanaan kegiatan ekstrakurukuler sepak bola, membuat pertandingan kegiatan ekstrakurukuler sepak bola, membimbing siswa dalam kegiatan ekstrakurukuler sepakbola, menyediakan program-program yang menarik dalam kegiatan ekstrakurukuler sepak bola, memberikan bimbingan khusus mengenai kegiatan ekstrakurukuler sepak bola, mengadakan kegiatan-kegiatan khusus dalam pelaksanaan kegiatan ekstrakurukuler sepak bola serta memberikan sebentuk hadiah kecil bagi siswa yang berprestasi dalam kegiatan ekstrakurukuler sepak bola.

Pelatih merupakan tonggak dalam permainan sepakbola karena pelatih akan mempermudah para pemain dalam melakukan permainan sepakbola, karena pelatih akan memberikan teknik bagaimana cara bermain sepakbola yang bagus. Keberhasilan pelaksanaan olah raga sepakbola sangat tergantung pada sikap dan komitmen guru penjas tersebut dilapangan. Senada dengan penyataan (Sari Mariati, 2018) "setiap pelatih dan pembina olahraga dalam memberikan latihan haru menggunakan metode latihan, karena dengan menggunakan metode latihan maka latihan dapat direncanakan dan dilaksanakan sesuai dengan tujuan dan kondisi yang ada".

Untuk kelancaran suatu pengajaran dan proses pembelajaran penjas sangat diperlukan sekali persiapan memadai. karena tanpa persiapan yang baik dan memadai suatu pengajaran pendidikan jasmani tidak bejalan dengan baik dan juga tidak akan mencapai sasaran yang diharapakan. Proses pembelajaran pendidikan olah raga sepakbola merupakan bentuk interaktif dari berbagai komitmen pendidikan dan pengajaran ,dari setiap komponen yaitu guru ,murid, dan kurikulum dan mempunyai 
peranan sesuai dengan fungsinya. Diantara komponen yang diantara kasikan tersebut guru merupakan komponen dasar yang harus mampu berjalan terhadap komponen lainnya. Tugas guru adalah menyusaun perencanan dan rancangan program kegiatan yang harus dilakukan siswa dalam upaya mencapai tujuan interaksional.oleh karena Itu guru dengan berorentasi kepada tujuan intruksional harus mempersiapakan pengajaran dengan baik.

Berdasarkan hasil penelitian ditemukan skor rata-rata indikator ketersediaan sarana dan prasaran 2,67 dengan Tingkat Capaian Responden (TCR) sebesar 53,42\%. Hal ini menunjukkan bahwa variabel ketersediaan saran dan prasarana dalam pelaksanaan ekstrakurikuler sepakbola masuk dalam kategori kurang. Dengan demikian dapat disimpulkan bahwa pada umumnya ketersediaan saran dan prasarana dalam pembelajarn ekstrakurikuler sepakbola masih kurang. Sarana dan prasarana yang menunjang dalam permainan sepakbola, karena sarana dan prasarana seperti bola, lapangan dan lainnya merupakan pondasi dalam permainan sepakbola. Sarana prasarana yang tidak memadai akan mempersulit berjalan permainan sepakbola.

Sepak Bola merupakan Olahraga yang banyak digemari oleh sebagian besar masyarakat di dunia, karena sepak bola dalam perkembangannya sudah kian melengkapi diri sebagai suatu cabang olahraga, ilmu, bahkan juga seni. Dan peratuan demi peraturan semakin lengkap dengan seiring berkembangnya zaman, dan diharapkan peraturan yang ada di dalamnya dapat dimengerti dan dilaksanakan oleh insan sepak bola. Perkembangan sepak bola juga didukung oleh Sarana dan Prasarana itu sendiri yang sesuai dengan aturan-aturan yang sudah ditetapkan.

Berdasarkan hasil penelitian ditemukan skor rata-rata indikator dukungan orang tua 2,90 dengan Tingkat Capaian Responden (TCR) sebesar 57,98\%. Hal ini menunjukkan bahwa variabel dukungan orang tua dalam pelaksanaan ekstrakurikuler sepakbola masuk dalam kategori kurang. Dengan demikian dapat disimpulkan bahwa pada umumnya orang tua kurang mendukung dalam pembelajarn ekstrakurikuler sepakbola masih kurang.

Aspek ekternal yang menunjang kegiatan sepakbola adalah dukungan orang tua, karena dukungan yang diberikan oleh orang terdekat merupakan motivasi eksternal yang menunjang seseorang lebih bersemangat dalam permainan sepakbola. Dukungan orang tua merupakan salah satu elemen sangat penting dalam konteks berolahraga. Seperti halnya faktor-faktor mental lainnya, dukungan orang tua seringkali mengalami fluktuasi.

Satu hal yang bisa menjadi faktor penentu peningkatan motivasi anak dalam kegiatan ekstra kurikuler sepakbola adalah peran orang tua. Hubungan yang positif dengan anak terbukti memberi efek yang positif terhadap peningkatan motivasi anak dalam berolahraga. Selanjutnya memprediksikan hubungan dengan orang tua serta teman sebaya dalam kaitannya dengan peningkatan motivasi dari anak-anak dalam berolahraga. Peran orang tua, juga dibutuhkan ketika anak memilih jenis olahraga yang tidak biasa, misalnya sepakbola walau anak berjenis kelamin wanita.

Membuat si kecil nyaman dengan olahraga yang dipilihnya, sudah menjadi dasar utama bagi anak untuk bisa merasakan mafaat dari olahraga. Selain olahraga rutin di sekolah atau di rumah, waktu libur bersama seharunya juga bisa dimanfaatkan untuk memastikan olahraga apa yang paling digemari anak. Cobalah rencanakan liburan ke daerah atau tempat wisata yang sejuk dengan suasana dan lokasi yang memungkinkan melakukan olahraga bersama.

Biarkan anak melakukan olahraga yang digemarinya. Sebenarnya susah-susah gampang membuat anak memiliki olahraga favorit baginya. Karena anak-anak masih cenderung mengikuti olahraga apa yang paling banyak dimainkan oleh teman-temannya. Motivasi ini menjadi salah satu elemen penting dalam menunjang keberhasilan seorang pemain sepakbola usia muda dalam menjalani karir permainannya. Anak-anak yang termotivasi akan mempunyai kecenderungan untuk menikmati aktivitas yang dilakukannya. Berkaitan dengan kesenangan ini, penelitian tersebut juga menemukan bahwa penerimaan yang positif dari teman sebaya serta hubungan dengan keluarga.

Sepakbola adalah salah satu cabang olahraga yang sudah memasyarakat di Indonesia. Hal ini dapat dilihat begitu banyak orang yang menggemarinya, baik sebagai penonton maupun langsung 
Sport Science: Jurnal Sain Olahraga dan Pendidikan Jasmani ISSN 114-562X (Cetak), ISSN XXXX-XXXX(Online)

http://sportscience.ppj.unp.ac.id/index.php/jss/index

sebagai pemain. Mulai dari perkotaan sampai pedesaan, dari kalangan anak-anak sampai orang tua, bahkan dari kaum wanita pun tidak mau ketinggalan. Alasan merekapun bermacam-macam, ada yang sekedar mengisi waktu luang, mencari hiburan, sampai yang ingin mencapai prestasi yang tinggi. Tempat dan waktu mereka bermainpun beragam pula sesuai dengan situasi dan kondisi yang mereka miliki, ada yang di pantai, halaman rumah, dalam ruangan, sampai lapangan yang sebenarnya.

Sepokbola merupakan salah satu olahraga favorit di semua kalangan, idealisnya sepakbola memiliki daya tarik sendiri dan dapat dimainkan oleh semua kalangan, dalam permainan sepakbola dilakukan oleh beberapa orang yang bekerja sama dengan satu tujuan. Pada dasarnya permainan sepakbola merupakan suatu usaha untuk menguasai bola dan untuk merebutnya kembali bila sedang dikuasai oleh lawan. Oleh karena itu, untuk dapat bermain sepakbola harus menguasai teknik-teknik dasar sepakbola yang baik. Untuk dapat menghasilkan permainan sepakbola yang optimal, maka seorang pemain harus dapat menguasai teknik-teknik dalam permainan. Teknik dasar bermain sepakbola adalah merupakan kemampuan untuk melakukan gerakan-gerakan atau mengerjakan sesuatu yang terlepas sama sekali dari permainan sepakbola.

\section{KESIMPULAN}

Berdasarkan hasil penelitian ditemukan skor rata-rata indikator dukungan pelatih 2,66 dengan Tingkat Capaian Responden (TCR) sebesar 53,16\%. Hal ini menunjukkan bahwa variabel dukungan pelatih dalam pelaksanaan ekstrakurikuler sepakbola masuk dalam kategori kurang Dengan demikian dapat disimpulkan bahwa pada umumnya pelatih kurang dalam memberikan dukungan kepada siswa dalam pembelajaran ekstrakurikuler sepakbola.

Berdasarkan hasil penelitian ditemukan skor rata-rata indikator ketersediaan sarana dan prasaran 2,67 dengan Tingkat Capaian Responden (TCR) sebesar 53,42\%. Hal ini menunjukkan bahwa variabel ketersediaan saran dan prasarana dalam pelaksanaan ekstrakurikuler sepakbola masuk dalam kategori kurang. Dengan demikian dapat disimpulkan bahwa pada umumnya ketersediaan saran dan prasarana dalam pembelajarn ekstrakurikuler sepakbola masih kurang.

Berdasarkan hasil penelitian ditemukan skor rata-rata indikator dukungan orang tua 2,90 dengan Tingkat Capaian Responden (TCR) sebesar 57,98\%. Hal ini menunjukkan bahwa variabel dukungan orang tua dalam pelaksanaan ekstrakurikuler sepakbola masuk dalam kategori kurang. Dengan demikian dapat disimpulkan bahwa pada umumnya orang tua kurang mendukung dalam pembelajarn ekstrakurikuler sepakbola masih kurang.

\section{DAFTAR RUJUKAN}

Asnaldi, A. (2015). Profesionalisme Guru Pendidikan Jasmani di Sekolah Dasar. Sport Science, 23(28), $1-15$.

Asnaldi, A. (2016). Hubungan Pendekatan Latihan Massed Practice Dan Distributed Practice Terhadap Ketepatan Pukulan Lob Pemain Bulutangkis. Jurnal MensSana. https://doi.org/https://doi.org/10.24036/jm.v1i2.51

Asnaldi, A., FIK-UNP, Z., \& M, M. (2018). Hubungan Motivasi Olahraga Dan Kemampuan Motorik Dengan Hasil Belajar Pendidikan Jasmani Olahraga Dan Kesehatan Siswa Sekolah Dasar Negeri 16 Sintoga Kecamatan Sintuk Toboh Gadang Kabupaten Padang Pariaman. Jurnal MensSana, 3(2), 16-27. https://doi.org/10.24036/jm.v3i2.75

Redawati, R., Asnaldi, A., \& Mardela, R. (2017). Persepsi Guru-Guru Non Penjas terhadap Pembelajaran Pendidikan Jasmani Olahraga Kesehatan dan Rekreasi Gugus IV Sungai Jambu Kecamatan Pariangan. Sport Science, 17(1), 10-18. https://doi.org/10.24036/JSS.V17I1.1 
Rosmawati. (2016). Hubungan Daya Ledak Otot Tungkai Dengan Kemampuan Shooting Pemain Club Futsal Sekolah Menengah Kejuruan Nusatama Padang. Jurnal MensSana, 1(2), 11-19. https://doi.org/https://doi.org/10.24036/jm.v1i2.49

Sari Mariati, W. R. (2018). Pengaruh Metode Latihan Sistem Sirkuit Terhadap Peningkatan Kemampuan Daya Ledak Otot Lengan Pada Atlet Bolabasket Fik Unp. Jurnal MensSana, 3(2), 28-36. https://doi.org/https://doi.org/10.24036/jm.v3i2.76 